\title{
Antimicrobial activity of flavonoids and steroids isolated from two Chromolaena species
}

\author{
Silvia Helena Taleb-Contini', Marcos José Salvador', Evandro Watanabe², Izabel Yoko Ito², \\ Dionéia Camilo Rodrigues de Oliveira ${ }^{2 *}$
}

\begin{abstract}
${ }^{1}$ Departamento de Química, Faculdade de Filosofia Ciências e Letras de Ribeirão Preto, Universidade de São Paulo,
${ }^{2}$ Departamentos de Física e Química e de Análises Clínicas, Toxicológicas e Bromatológicas, Faculdade de Ciências Farmacêuticas de Ribeirão Preto, Universidade de São Paulo
\end{abstract}

*Correspondence:

D. C. R. de Oliveira

Departamento de Física e Química Faculdade de Ciências Farmacêuticas de Ribeirão Preto, USP

Av. do Café, s/n

14040-903, Ribeirão Preto - SP, Brasil

E mail: drolivei@fcfrp.usp.br
The crude extracts (dichloromethanic and ethanolic) and some compounds (8 flavonoids and 5 steroids) isolated from Chromolaena squalida (leaves and stems) and Chromolaena hirsuta (leaves and flowers) have been evaluated against 22 strains of microorganisms including bacteria (Gram-positive and Gram-negative) and yeasts. All crude extracts, flavonoids and steroids evaluated have been shown actives, mainly against Gram-positive bacteria.

\section{INTRODUCTION}

Flavonoids are phenolic substances widely distributed in all vascular plants. They are a group of about 4000 naturally compounds known, and have been shown to have contribute to human health through our daily diet. They are ubiquitous in plant foods and drinks such as fruits, vegetables, tea, wine, coffee and beer (Giulia et al., 1999).

In a review, discussed by Harborne and Willians (2000), many studies have suggested that flavonoids exhibit antioxidant, anti-inflamatory, antimicrobial, vascular activities and others medicinal properties. Many reports on the antimicrobial activity of flavonoids are available (Baez et al., 1999; Xu, Lee, 2001; Ogundipe et al., 2001). Related studies of antimicrobial activity indicate that crude extracts containing flavonoids, triterpenes and steroids have showed significative activity against various strains of Staphylococcus aureus, Streptococcus faecalis and Escherichia coli (Chattopadhay et al., 2001).

Antibacterial effect against eight strains of Grampositive and Gram-negative bacteria (Minimum Inhibitory
Concentration (MIC) in the range of 64 to $250 \mu \mathrm{g} / \mathrm{mL}$ ) was showed for crude extract of Castanea sativa. The analyse by TLC and HPLC of the active fraction showed the presence of flavonoids rutin, hesperidin, quercetin, apigenin, morin, naringin, galangin and kaempferol. Standards of these flavonoids were assayed against the same bacterial strains, and the highest activity was shown by quercetin, rutin and apigenin (Basile et al., 2000).

Antimicrobial screening of 13 phenolic substances was carried out by diffusion methods against Aspergillus niger, Bacillus subtilis, Candida albicans, Escherichia coli, Micrococcus luteus, Pseudomonas aeruginosa, Saccharomyces cerevisiae, Staphylococcus nervous and Staphylococcus epidermidis. The flavonoids flavone, quercetin and naringenin inhibited the growth of these organisms (Rauha et al., 2000).

The ocurrence of flavonoids on crude extracts of $C$. squalida and C. hirsuta (Asteraceae-Eupatorieae) is of the great interest to discover new plant derived-compounds. It lead us to evaluate the antimicrobial activity of these extracts and some isolated compounds. 


\section{MATERIAL AND METHODS}

\section{General experimental procedure}

The IR spectra were obtained on $\mathrm{KBr}$ pellets in a Perkin Elmer model 1420 spectrophotometer. ${ }^{1} \mathrm{H}$ NMR $(300 \mathrm{MHz})$ and the ${ }^{13} \mathrm{C}$ NMR $(75 \mathrm{MHz})$ spectra were recorded on a Brucker Avance DPX 300; and the ${ }^{1} \mathrm{H}$ NMR (400 MHz) and ${ }^{13} \mathrm{C}$ NMR (100 MHz) spectra were recorded on a Brucker-Avance DPX 400, in $\mathrm{CDCl}_{3}$ and DMSO- $d_{6}$ with TMS as internal standard. The UV spectra were obtained in Hitachi U-3501 spectrophotometer. TLC was carried out on Si gel PF-254 (Merck), CC on Si gel 60 (0.063-0.200), (Merck) and CC on Sephadex LH 20 (Sigma, 25-100 $\mu$ ).

\section{Plant material of Chromolaena squalida}

Aerial parts (leaves and stems) of C. squalida (ex E. squalidum) was collected by Prof. Dr. N. P. Lopes in Furnas, a town in the state of Minas Gerais - Brazil, in April 1998, and identified by Prof. Dr. E. E. Schilling (University of Tennessee - Knoxville, TN, USA) and Prof. Dr. H. Robinson (Department of Botany, Smithsonian Institute, Washington D.C., USA). The voucher specimen (NPL 126) was deposited in the Herbarium of the Department of Biology, FFCLRP/USP, Brasil, SPFR 04414.

\section{Extraction and preparation of test solutions}

Test solutions were prepared in DMSO/sterile water $(5: 95)$ at $1000 \mu \mathrm{g} / \mathrm{mL}$ for the crude extracts from $C$. squalida (leaves and stems) and C. hirsuta (leaves and flowers) and at $500 \mu \mathrm{g} / \mathrm{mL}$ for each isolated compounds (flavonoids and mixture of steroids).

\section{Isolation of compounds from Chromolaena species}

Dried and pulverized leaves (73 g) and stems (64 g) of $C$. squalida were extracted at room temperature with $\mathrm{CH}_{2} \mathrm{Cl}_{2}$ and then EtOH, separately, to give the respective crude extracts.

The $\mathrm{CH}_{2} \mathrm{Cl}_{2}$ crude extract of leaves Csd1 (3.91 g) and stem Csd2 ( $0.75 \mathrm{~g}$ ) were chromatographed over Silica gel 60 (CC), eluting with hexane and gradually increasing the polarity with EtOAc and then $\mathrm{MeOH}$.

From the Csd1 crude extract was extracted the flavonoid $1(0.007 \mathrm{~g})$. The crude extract Csd2 furnished the mixture $(0.012 \mathrm{~g})$ of steroids stigmasterol $\mathbf{9}, \beta$ sitosterol 10, campesterol 11, espinasterol 12, $\Delta^{7}$ stigmastenol 13.
The EtOH crude extract of leaves Cse1 (2.08 g) was chromatographed on Sephadex LH-20, eluting with $\mathrm{MeOH}$. All collected fractions were monitored by TLC, and the reunited fractions were purified by chromatographic process. This extract furnished the flavonoid $\mathbf{2}$ (0.012 g).

Dichloromethanic and ethanolic crude extracts (leaves and flowers) of $C$. hirsuta were previously studied (Taleb-Contini, 2002; Taleb-Contini, Oliveira, 2000). It resulted in isolation of the flavonoids 3-8 which were, in this study, evaluated for antimicrobial activity.

The structures of the flavonoids are presented on Figure 1.
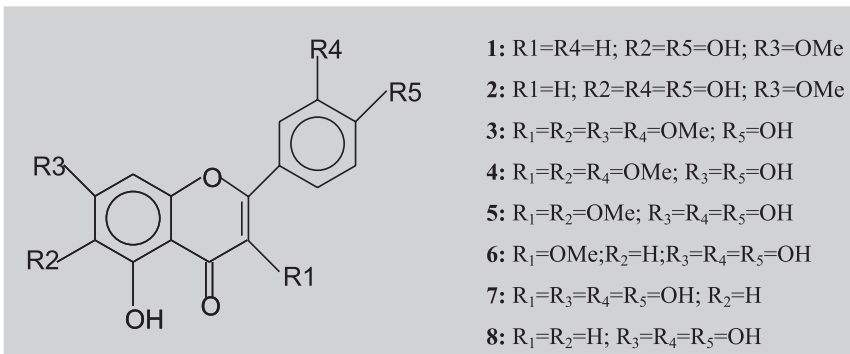

FIGURE 1 - Flavonoids from Chromolaena species evaluated for antimicrobial activity.

\section{Microorganisms strains}

Twenty two strains of bacteria (Gram-positive and Gram-negative) and yeasts were used in the antimicrobial assays. The following microorganisms were used: Escherichia coli - ATCC 10538; E. coli - 26.1 (field strain); Pseudomonas aeruginosa - ATCC 27853; P. aeruginosa - Pn (field strain); Micrococcus luteus - ATCC 9341; Staphylococcus aureus - ATCC 25923, 6538 and 29213; S. aureus - 7+ penicillinase producer; S. aureus 8-penicillinase non-producer; Staphylococcus epidermidis - 6ep (field strains); Candida albicans - ATCC 1023; Candida albicans-cas and Candida tropicalis - ct (field strains), cultivated for 24 hours at $37^{\circ} \mathrm{C}$ in Mueller Hinton broth (Difco)-MHb; Enterococcus faecalis - ATCC 10541; Streptococcus mutans - ATCC 25175; S. mutans (strains Fab3; 87.1; 203.1; 211.1; 213.1) and Streptococcus sobrinus - 87.3 (field strains) incubated for 24 hours at $37^{\circ} \mathrm{C}$ in Brain Heart Infusion (Difco) - BHI. The standart strains and field strains (oral cavity) were collected from Departamento de Análises Clínicas, Toxicológicas e Bromatológicas, Faculdade de Ciências Farmacêuticas de Ribeirão Preto, Universidade de São Paulo, Ribeirão Preto (SP), Brasil. 


\section{Determination of antimicrobial activity}

The inoculum size of each test strain was standardized according to the National Committee for Clinical Laboratory Standards (NCCLS, 1993). The test bacterial and yeasts strains were inoculated into Mueller Hinton broth (Difco) - MHb agar plates (Escherichia, Pseudomonas, Micrococcus, Staphylococcus and Candida strains) and Brain Heart Infusion (Difco)-BHI plates (Enterococcus and Streptococcus strains), containing an inoculum size of $10^{6} \mathrm{cfu} / \mathrm{mL}(0.5 \mathrm{McF}$ arland scale).

Antimicrobial activity was performed by the well diffusion method (well technique in double layer) (Cole, 1994; Grove, Randall, 1955).

A volume the $20 \mu \mathrm{L}$ of each test-drug solution were applied into $5.0 \mathrm{~mm}$ diameter wells. After holding the plates at room temperature for 2 hours to allow diffusion of test-drug into the agar, they were incubated at $37^{\circ} \mathrm{C}$ for 24 hours and the inhibition zone, corresponding to the halo
(H) formed from well edge to the beginning of the region of microbial growth was measured in millimeters $(\mathrm{mm})$. The MIC was determined in $\mu \mathrm{g} / \mathrm{mL}$ for each isolated compound with concentration between 25 and $500 \mu \mathrm{g} / \mathrm{mL}$ (Salvador et al., 2002; Okeke et al., 2001; Okunji et al., $1990)$. In these tests, bacitracine $(0.2 \mathrm{UI} / \mathrm{mL})$, gentamicine discs $(10 \mu \mathrm{g})$ and ketoconazole $(100 \mu \mathrm{g} / \mathrm{mL})$ were used as experimental positive controls for microorganism strains and DMSO/sterile water $(5: 95)$ as negative control for which no inhibitory effect could be observed. The bioassays were performed in duplicate for each strain of microorganism evaluated.

\section{RESULTS AND DISCUSSION}

The identities of steroids stigmasterol, $\beta$-sitosterol, campesterol, espinasterol and $\Delta^{7}$-stigmasterol were confirmed by GC analysis, using authentic samples.

The bioactive flavonoids $\mathbf{1}$ and $\mathbf{2}$ were caracterized by comparing physical and spectroscopic properties $\left({ }^{1} \mathrm{H}\right.$,

TABLE I - Antimicrobial activity of crude extracts of C. squalida (leaves and stem) and C. hirsuta (leaves and flowers)

\begin{tabular}{|c|c|c|c|c|c|c|c|c|c|c|c|}
\hline Microorganisms & $\begin{array}{c}\text { Csd1 } \\
\text { H }\end{array}$ & $\begin{array}{c}\text { Cse1 } \\
\text { H }\end{array}$ & $\begin{array}{c}\text { Csd2 } \\
\text { H }\end{array}$ & $\begin{array}{c}\text { Cse2 } \\
\text { H }\end{array}$ & $\begin{array}{c}\text { Chd1 } \\
\text { H }\end{array}$ & $\begin{array}{c}\text { Che1 } \\
\text { H }\end{array}$ & $\begin{array}{c}\text { Chd3 } \\
\text { H }\end{array}$ & $\begin{array}{c}\text { Che3 } \\
\text { H }\end{array}$ & $\begin{array}{l}\text { B } \\
\text { H }\end{array}$ & $\begin{array}{l}\mathbf{G} \\
\mathbf{H}\end{array}$ & $\begin{array}{l}\mathbf{K} \\
\mathbf{H}\end{array}$ \\
\hline M. luteus (ATCC 9341) & - & - & - & - & - & - & - & - & 25 & 28 & - \\
\hline S. aureus (ATCC 6538) & 7 & - & 8 & - & 6 & 9 & 13 & 6 & 23 & 26 & - \\
\hline S. aureus (ATCC 25923) & 6 & - & 7 & - & 6 & 7 & 10 & - & 29 & 28 & - \\
\hline S. aureus (ATCC 29213) & 8 & - & - & - & 6 & 8 & 9 & - & 29 & 28 & - \\
\hline S. aureus $(7+)^{c}$ & 8 & 7 & 8 & - & 6 & 7 & 11 & 7 & 25 & 28 & - \\
\hline S. aureus $(8-)^{c}$ & 8 & - & 7 & - & 7 & 8 & 13 & 6 & 25 & 26 & - \\
\hline S. epidermidis $(6 \mathrm{ep})^{\mathrm{c}}$ & 6 & - & 6 & - & 7 & 7 & 12 & - & 31 & 27 & - \\
\hline E. faecalis (ATCC 10541) & - & - & - & - & - & - & 8 & - & 28 & 22 & - \\
\hline S. mutans (ATCC 25175) & - & - & - & - & 6 & 7 & - & - & 24 & 23 & - \\
\hline S. mutans (Fab3) ${ }^{\mathrm{b}}$ & - & - & 6 & - & 6 & 8 & - & - & 24 & 24 & - \\
\hline S. mutans $(87.1)^{\mathrm{c}}$ & 6 & 6 & - & - & 6 & 7 & 7 & 6 & 24 & 20 & - \\
\hline S. mutans $(203.1)^{\mathrm{c}}$ & - & - & - & - & 7 & 7 & 6 & 6 & 22 & 21 & - \\
\hline S. mutans $(211.1)^{\mathrm{c}}$ & - & - & - & - & - & - & - & 6 & 22 & 20 & - \\
\hline S. mutans $(213.1)^{\mathrm{c}}$ & - & - & - & - & 6 & - & - & - & 22 & 22 & - \\
\hline S. sobrinus $(87.3)^{\mathrm{c}}$ & - & - & 6 & 6 & - & 7 & - & - & 23 & 24 & - \\
\hline E. coli $(\mathrm{ATCC} 10538)^{\mathrm{b}}$ & - & - & - & - & - & - & - & - & 30 & 30 & - \\
\hline E. $\operatorname{coli}(26.1)^{\mathrm{c}}$ & - & - & - & - & - & - & - & - & 32 & 30 & - \\
\hline P. aeruginosa (ATCC 27853) & - & - & - & - & - & - & - & & 22 & 25 & - \\
\hline$P$ aeruginosa $(\mathrm{Pn})^{\mathrm{c}}$ & - & - & - & - & - & - & - & - & 22 & 24 & - \\
\hline C. albicans (ATCC 1023) & - & - & - & - & - & - & - & - & - & - & 30 \\
\hline C. albicans (cas) ${ }^{\mathrm{c}}$ & - & - & - & - & - & - & - & - & - & - & 30 \\
\hline C. tropicalis $(\mathrm{ct})^{\mathrm{c}}$ & - & - & - & - & - & - & - & - & - & - & 15 \\
\hline
\end{tabular}

$-=$ absence of inhibition of microbial growth at $1000 \mathrm{mg} / \mathrm{mL} ; \mathrm{H}=$ halo of inhibition $(\mathrm{mm})$; Diluent $=\mathrm{DMSO} /$ sterile water (5:95); $\mathrm{B}=$ Bacitracine, $0.2 \mathrm{UI} / \mathrm{mL} ; \mathrm{G}=$ Gentamicine discs, $10 \mathrm{mg} ; \mathrm{K}=$ Ketoconazole, $100 \mathrm{mg} / \mathrm{mL}$; Csd1 = C. squalida dichloromethanic leaves; $\mathrm{Csd} 2=$ C. squalida dichloromethanic stem; Cse1 $=$ C. squalida ethanolic leaves; Cse2 =C. squalida ethanolic stem; Chd $1=C$. hirsuta dichloromethanic leaves; $\mathrm{Chd} 3=C$. hirsuta dichloromethanic flowers; $\mathrm{Che} 1=C$. hirsuta ethanolic leaves; Che $3=C$. hirsuta ethanolic flowers crude extracts; ${ }^{b}=$ standard strains; ${ }^{\mathrm{c}}=$ field strains (oral cavity). 
${ }^{13} \mathrm{C}$ NMR, IR and UV) spectra, with those reported in the literature, i.e. 1 (Silva et al., 1977), 2 (Saúl-Escarria et al., 1977). The spectral date of ${ }^{1} \mathrm{HNMR}$ showed the proton resonances commoly found in flavonoids and their substituents. Ultraviolet-visible absorption spectroscopy was useful to aid both identification of the flavonoid type and definition of the oxygenation pattern.

All the crude extracts (ethanolic and dichloromethanic) from leaves and stems of C. squalida and leaves and flowers from $C$. hirsuta showed antimicrobial activity, mainly against Gram-positive (Staphylococcus and Streptococcus) bacteria, at $1000 \mathrm{mg} / \mathrm{mL}$ (Table I).

The evaluated compounds showed actives at least against two indicative strains used (Table II). The flavonoids $\mathbf{6}, 7$ and $\mathbf{8}$ were the most bioactives. The mixture of steroids $(500 \mathrm{mg} / \mathrm{mL})$ showed to be active mainly against Streptococcus mutans and S. sobrinus strains, however with very limited activity. The flavonoids $\mathbf{1}$ and $\mathbf{2}$ were active against $S$. aureus (ATCC 6538 and ATCC 29213), S. sobrinus (87.3) and Enterococcus faecalis (ATCC-10541) strains.

From all test-drug only the flavonoid 7 showed activity against the Gram-negative (Escherichia coli and
Pseudomonas aeruginosa) bacteria and yeast (Candida albicans and C. tropicalis).

The results reveal that the most bioactive flavonoids are those that have dyhydroxy groups at C3' and C4' positions, a hydroxy substituent at position $\mathrm{C} 7$, and the position C6 unsubstituted.

The structure-activity relantionships become very interesting when we compare the structures of flavonoids 6, 7 and 8 . They all have a group hydroxy at positions $\mathrm{C} 7$, C3' and C4', but only the flavonoid 7 (that exhibited activity against Gram-negative bacteria and yeast) has a hydroxy group at $\mathrm{C} 3$ position. The flavonoids $\mathbf{1}$ and $\mathbf{2}$ that show the same substitution pattern of A ring and the $\mathrm{C} 3$ unsubstituted, were found to be active against the same bacterial strains, problaby acting by the same mechanism of action. However, it is necessary to make profound studies to better understand the mechanism of action of these evaluated substances.

\section{CONCLUSION}

Ethanolic and dichloromethanic crude extracts from leaves and stems of C. squalida and leaves and flowers from

TABLE II - Antimicrobial activity of compounds isolated from C. squalida and C. hirsuta

\begin{tabular}{|c|c|c|c|c|c|c|c|c|c|}
\hline \multirow[t]{2}{*}{ Microorganisms } & \multirow[b]{2}{*}{1} & \multicolumn{8}{|c|}{ Evaluated material MIC $(\mu \mathrm{g} / \mathrm{mL})$} \\
\hline & & 2 & 3 & 4 & 5 & 6 & 7 & 8 & $9-13$ \\
\hline M. luteus (ATCC 9341) ${ }^{\mathrm{b}}$ & - & - & 100 & 500 & 50 & - & 500 & - & - \\
\hline S. aureus (ATCC 6538) & 100 & 500 & - & 500 & 500 & 100 & 100 & 500 & - \\
\hline S. aureus (ATCC 25923) & - & 500 & - & - & 500 & - & 100 & 100 & - \\
\hline S. aureus (ATCC 29213) & 100 & 500 & 100 & - & - & 100 & 100 & - & - \\
\hline S. aureus $(7+)^{c}$ & - & - & 500 & - & - & 500 & 100 & 500 & 500 \\
\hline S. aureus $(8-)^{c}$ & - & - & - & - & - & 100 & 100 & - & - \\
\hline S. epidermidis $(6 \mathrm{ep})^{\mathrm{c}}$ & 500 & 500 & - & - & - & 100 & 100 & - & - \\
\hline E. faecalis (ATCC 10541) & 500 & 500 & - & - & - & 500 & 100 & - & - \\
\hline S. mutans (ATCC 25175) & - & - & - & - & - & - & 500 & 500 & 500 \\
\hline S. mutans $(\mathrm{Fab} 3)^{\mathrm{b}}$ & - & - & - & - & - & - & 50 & - & - \\
\hline S. mutans $(87.1)^{\mathrm{c}}$ & - & - & - & - & - & 100 & 100 & - & 500 \\
\hline S. mutans $(203.1)^{\mathrm{c}}$ & - & - & - & - & - & 500 & - & - & 500 \\
\hline S. mutans $(213.1)^{\mathrm{c}}$ & - & - & - & - & - & 500 & 100 & - & - \\
\hline S. mutans $(211.1)^{\mathrm{c}}$ & - & - & - & - & - & 500 & 500 & - & - \\
\hline S. sobrinus $(87.3)^{\mathrm{c}}$ & 500 & 500 & - & - & 500 & 100 & 100 & 500 & 500 \\
\hline E. coli $(\text { ATCC 10538) })^{\mathrm{b}}$ & - & - & - & - & - & - & 500 & 500 & - \\
\hline E. $\operatorname{coli}(26.1)^{\mathrm{c}}$ & - & - & - & - & - & - & 100 & 500 & - \\
\hline P. aeruginosa (ATCC 27853) & - & - & - & - & - & - & 100 & - & - \\
\hline P. aeruginosa $(\mathrm{Pn})^{\mathrm{c}}$ & - & - & - & - & - & - & 100 & - & - \\
\hline C. albicans (ATCC 1023) & - & - & - & - & - & - & 500 & - & - \\
\hline C. albicans (cas) ${ }^{\mathrm{c}}$ & - & - & - & - & - & - & 500 & - & - \\
\hline C. tropicalis (ct) ${ }^{\mathrm{c}}$ & - & - & - & - & - & - & 500 & - & - \\
\hline
\end{tabular}

- = absence of inhibition of microbial growth until $500 \mathrm{mg} / \mathrm{mL}$; MIC = Minimum Inhibitory Concentration $(\mathrm{mg} / \mathrm{mL})$;

$\mathrm{b}=$ standard strains; $^{\mathrm{c}}=$ field strains (oral cavity) 
C. hirsuta showed antimicrobial activity, mainly against Gram-positive (Staphylococcus and Streptococcus) bacteria.

All the evaluated compounds showed to be bioactive, mainly the flavonoids $\mathbf{6 , 7}$ and $\mathbf{8}$.

\section{ACKNOWLEDGEMENTS}

The authors are grateful to Fundação de Amparo à Pesquisa do Estado de São Paulo (FAPESP), CAPES and CNPq for financial support and FAPESP, for a graduate fellowship to S.H.T.; to Prof. E.E. Schilling and Prof. H. Robinson for plant identification.

\section{RESUMO}

\section{Atividade antimicrobiana de flavonóides e esteróides isolados de duas espécies de Chromolaena}

Os extratos diclorometânicos e etanólicos de folhas e caule de Chromolaena squalida e de folhas e flores de Chromolaena hirsuta foram avaliados quanto à atividade antimicrobiana. Oito flavonóides e cinco esteróides foram desafiados frente a 22 cepas indicadoras, incluindo bactérias (Gram-positivas e Gram-negativas) e leveduras. Todos os extratos brutos, flavonóides e esteróides ensaiados mostraram atividade antimicrobiana, principalmente frente a bactérias Gram-positivas.

UNITERMOS: Chromolaena. Asteraceae. Flavonóides. Esteróides. Atividade antimicrobiana.

\section{REFERENCES}

BAEZ, D. A.; VALLEJO, L. G. Z.; JIMENEZ-ESTRADA, M. Phytochemical studies on Senna skinneri and Senna wishizeni. Nat. Prod. Lett., Berks, v. 13, p. 223-228, 1999.

BASILE, A.; SORBO, S.; GIORDANO, S.; RICCIARDI, L.; FERRARA, S.; MONTESANO, D.; COBIANCHI, R. C.; VUOTTO, M. L.; FERRARO, L. Antibacterial and allelopathic activity of extract from Castanea sativa leaves. Fitoterapia, Milano, v. 71, p. 110-116, 2000.

CHATTOPADHYAY, D.; MAITI, K.; KUNDU, A. P.; CHAKRABORTY, M. S.; BHADRA, R.; MAUDAL, S. C.; MAUDAL, A. B. Antimicrobial activity of Alstonia macrophylla: A folklore of bay islands. $J$. Ethnopharmacol., Lausanne, v. 77, p. 49-55, 2001.
COLE, M. D. Key antifungal, antibacterial and anti-insect assays - a critical rewiew. Biochem. Syst.Ecol., Oxford, v. 22, p.837-856, 1994.

GIULIA, D. C.; NICOLA, M.; ANGELO, A.; FRANCESCO, C. Flavonoids: Old and new aspects of a class of natural therapeutic drugs. Life Sci., Oxford, v. 65, p. $337-353,1999$.

GROVE, D. C.; RANDALL, W. A. Assay methods of antibiotics: a laboratory manual [Antibiotics monographs, 02]. New York: Medical Encyclopedia Inc., $1955.80 \mathrm{p}$.

HARBORNE, J. B.; WILLIANS, C. A. Advances in flavonoid research since 1992. Phytochemistry, Oxford, v. 55, p. 481-504, 2000.

NATIONAL COMMITTEE FOR CLINICAL LABORATORY STANDARDS. Methods for dilution in antimicrobial susceptibility tests. Approved standard M2-A5. National Committee for Clinical Laboratory Standard, Villanova, PA, 1993.

OGUNDIPE, O. O.; MOODY, J. O.; HOUGHTON, P. J.; ODELOLA, H. A. Bioactive chemical constituents from Alchormea laxiflora (benth) pax and hoffman. J. Ethnopharmacol., Lausanne, v. 74, p. 275-280, 2001.

OKEKE, M. J.; IROEGBU, C. U.; EZE, E. N.; OKOLI, A. S.; ESIMONE, C. O. Evaluation of extracts of the root of Landolphia owerrience for antibacterial activity. $J$. Ethnopharmacol., Lausanne, v. 78, p. 119-127, 2001.

OKUNJI, C. O.; OKEKE, C. N.; GUGNANI, H. C.; JWU, M. M. Antifungal saponin from fruit pulp of Dracaena manni. Int.J.Crude Drug Res., Lisse, v. 28, p. 193-199, 1990.

RAUHA, J. P.; REMES, S.; HEINONEN, M.; HOPIA, A.; KAHKONEN, M.; KUYALA, T.; PIHLAYA, K.; VUORELA, H.; VUORELA, P. Antimicrobial effects of Finnish plant extracts containing flavonoids and other phenolic compounds. Int.J.Food Microbiol., Amsterdam, v. 56, p. 3-12, 2000.

SALVADOR, M. J.; FERREIRA, E. O.; PRAL, E. M. F.; ALFIERI, S. C.; ALBUQUERQUE, S.; ITO, I. Y.; DIAS, D. A. Bioactivity of crude extracts and some constituents of Blutaparon portulacoides (Amaranthaceae). Phytomedicine, Jena, v. 9, p. 566-571, 2002. 
SAÚL-ESCARRIA, R.; TORRENEGRA, R. D.; ANGARITA, B. Colombian plants of the genus Gnaphalium. Phytochemistry, Oxford, v. 16, p. 16181619, 1977.

SILVA, M.; WISENFELD, A.; SAMMES, P.G.; TYLER, T.W. New sesquiterpenes from Pleocarphus Revolutus. Phytochemistry, Oxford, v. 16, p. 379-385, 1977.

TALEB-CONTINI, S. H. Fitoquímica de duas espécies de Chromolaena (Eupatorieae-Asteraceae). Ribeirão Preto, 2002. 224p. [Tese (Doutorado em Química). Faculdade de Filosofia, Ciências e Letras de Ribeirão Preto da Universidade de São Paulo].
TAlEB-CONTINI, S. H.; OLIVEIRA, D. C. R. Constituintes químicos de Chromolaena hirsuta (Hook. \& Arn.) R. King \& H. Robinson (EuparorieaeAsteraceae). In: REUNIÃO ANUAL DA SOCIEDADE BRASILEIRA DE QUÍMICA, 23., 2000, Poços de Caldas. Livro de Resumos. São Paulo: SBQ, 2000. v. 2, p. PN-057.

XU, H. X.; LEE, S.F. Activity of plant flavonoids against antibiotic-resistant bacteria. Phytother. Res., London, v. 15, p. 39-43, 2001.

Recebido para publicação em 19 de novembro de 2002. 